\section{Pemberian Kompos Jerami dan Tepung Cangkang Telur pada Tanaman Kangkung di Desa Mallinrung Kec. Libureng Kab. Bone Provinsi Sulawesi Selatan}

\author{
Muhammad Nur Ichwan \\ Sutoyo \\ Eny Wahyuning Purwanti
}

\section{BIONATURE}

p-ISSN 1411 - 4720

e-ISSN 2654 - 5160

Abstract. This study was to determine the type of organic fertilizer treatment that can give the best results on kale plants. The independent sample t-test was used to compare the two types of organic fertilizer treatments. The treatments include straw compost and eggshell flour with each treatment being repeated 30 times. The dose of fertilizer used was $26.810 \mathrm{~g}$ for each kale plant. The results showed that there was no significant difference between the two treatments of organic fertilizers which were given both straw compost and eggshell flour with a dose of $26.810 \mathrm{~g}$ on the parameters of the observation of fresh harvest weight and power save plant. Keywords: straw compost, eggshell flour, kale plants yang digunakan adalah $26.810 \mathrm{~g}$ untuk setiap tanaman kangkung. Hasil penelitian menunjukkan bahwa tidak terdapat perbedaan yang signifikan antara kedua perlakuan pupuk organikyang diberi kompos jerami dan tepung kulit telur dengan dosis 26,810 g pada parameter pengamatan bobot segar panen dan daya simpan tanaman.

Kata Kunci: kompos jerami, tepung cangkang telur,tanaman kangkung

\section{Pendahuluan}

Besarnya potensi hasil pertanian Indonesia yang salah satunya di bidang tanaman hortikultura memberikan kesempatan emas dalam peningkatan hasil pertanian yang semakin tinggi, Peningktan hasil pertanian, tidak bisa lepas dari peran dan pemanfaatan teknologi. Pemupukan dan penggunaan pupuk yang tepat merupakan salah satu teknologi budidaya yang dapat meningkatkan produksi pertanian. Tanaman sayuran merupakan salah satu hasil pertanian yang dibutuhkan oleh daerah setempat secara konsisten untuk memenuhi kebutuhan pangan yang sehat. Sejalan dengan peningkatan jumlah penduduk, tingkat sekolah dan tingkat keuangan daerah, kebutuhan akan sayuran semakin meningkat. Salah satu komoditas sayur yang merakyat dan banyak dibudidayakan adalah tanaman kangkung. Secara umum terdapat 2 jenis tanaman kangkung yaitu kangkung air (Ipomea Aquatica) dan kangkung darat (Ipomea. reptans). Kangkung yang banyak dibudidayakan di masyarakat adalah kangkung darat, dan spesies yang banyak tersebar di masyarakat adalah jenis Ipomea. Batatas L. Di dalam pembudidayaannya kangkung darat biasanya banyak ditanam di lahan yang kecil dan bertektur remah, tetapi banyak juga yang ditanam di lahanlahan pekarangan. Saat ini,petani kebanyakan belum mengetahui budidaya tanaman secara organik khususnya di desa Mallinrung padahal melihat keadaan sekarang dengan tingginya pencemaran hasil dari aktivitas pertanian penting bagi kita menerapkan sistem pertanian berkelanjutan merupakan salah satu pilhan yang banyak
Muhammad Nur Ichwan Polbangtan Malang Indonesia

Sutoyo

Polbangtan Malang Indonesia

Eny Wahyuning Purwanti Polbangtan Malang Indonesia 
disarankan oleh ahli pertanian, selain murah hal ini juga dapat menurunkan jumlah limbah, khususnya pertanian.

Besarnya potensi limbah pertanian khususnya jerami dapat dimanfaatkan untuk budidaya tanaman hortikultura yakni karena di dalam jerami tersebut terdapat kandungan unsur: Nitrogen $(\mathrm{N}) 2,11 \%$, Fosfor $\left(\mathrm{P}_{2} \mathrm{O}_{5}\right)$ 0,64\%, Kalium $\left(\mathrm{K}_{2} \mathrm{O}\right)$ 7,7\% yang dibutuhkan tanaman dalam proses tumbuh kembangnya (Rohmawati, D. 2016 ),oleh karena itu di setiap kali waktu panen menjadi perhatian penting untuk dilakukan penanganan yang baik agar limbah dapat di olah dengan baik sehingga menekan pencemaran lingkungan. Salah satu metode pengolahan limbah pertanian yang bisa dilakukan yakni dengan mengolah limbah jerami menjadi pupuk organik yang dapat mengurangi laju pertambahan emisi $\mathrm{CO}_{2}$ yang dapat berakibat buruk dalam jangka Panjang dan juga memberdayakan petani guna menerapkan Pengelolaan Tanaman Terpadu (PTT). Selain limbah jerami, limbah rumah tangga juga menjadi hal penting di tangani karena paling dekat dengan aktivitas manusia, salah satu limbah yang belum banyak di manfaatkan salah satunya adalah cangkang telur. Cangkang telur mengandung Unsur kalsium karbonat $\left(\mathrm{CaCO}_{3}\right)$ yang juga dapat di manfaatkan sebagai pupuk organik sebagaimana dalam penelitian menunjukkan bahwa cangkang telur memiliki kandungan $\mathrm{CaCO}_{3}$ 95\% Butcher dan Miles, 1990 (Syam, Z. Z., Kasim, H. A., \& Nurdin, H. M. 2014). Disamping mengurangi efek buruk, petani juga dapat memanfaatkan hasil kompos jerami sebagai pupuk budidaya sayuran berskala rumah tangga seperti kangkung yang banyak di gemari masyarakat khususnya di Desa Mallinrung.

Salah satu permasalahan yang umum di temui adalah kurangnya pengelolaan limbah jerami padi. Kegiatan petani yang hanya membiarkan begitu saja limbah jeraminya dan membakar jerami sebaiknya di upayakan untuk mulai melakukan pemanfaatan limbah tersebut menjadi pupuk kompos,selain itu pula limbah rumah tangga berupa cangkang telur juga dapat dimanfaatkan menjadi pupuk organik. Pupuk ini dapat di aplikasikan pada tanaman hortikultura seperti tanaman sayur,salah satu sayur yang digemari oleh masyarakat adalah tanaman kangkung. Pemerintah telah mengupayakan pengembangan usaha tani selain padi untuk mengembangkan pertanian,kangkung menjadi pilihan yang baik untuk di perkenalkan kepada masyarakat,dengan membudidayakan kangkung yang pupuknya dapat bersumber dari jerami dan cangkang telur. Kurangnya pemanfaatan limbah jerami dan cangkang telur diharapkan dapat diatasi serta masyarakat akan mendapatkan sayuran berbasis organik yang murah dan mudah nantinya.

\section{Metode Penelitian}

Penelitian dilaksanakan di Desa Mappesangka Kecamatan Ponre Kabupaten Bone. Waktu pelaksanaan penelitian dimulai pada bulan Februari 2021 sampai April 2021. Alat yang digunakan dalam pelaksanaan penelitian ini antara lain: Pacul dan linggis,Timbangan digital,Kardus Bekas dan Kertas koran, Gelas Plastik, Baskom/Wadah kompos dan cangkang telur, Polybag ukuran 17X35 cm, ATK (Spidol, selotip sayur, kertas HVS A4), Sendok dan tali rafiah, Ranting kayu dan daun kelapa sedangkan untuk bahan yang digunakan yaitu: Kompos, Benih Kangkung, Tepung Cangkang telur.

Pelaksanaan penelitian ini dilakukan dengan melakukan penanaman langsung benih kangkung pada media polybag yang di isi dengan tanah, setelah itu pada umur 10 HST tanaman diberikan 2 perlakuan berupa pengaplikasian jenis pupuk organic yang berberbeda dengan dosis yang ditentukan di dalam penelitian ini.

Rancangan percobaan yang di gunakan (independent sampel t-test) Uji -T yang terdiri dari dua perlakuan dengan 30 kali ulangan dari masing-masing perlakuan sehingga menghasilkan 60 sampel percobaan. Hal dilakukan guna untuk mengetahui perbedaan beda nyata dan tidak beda nyata antara perlakuan satu (P1) Tanah+Kompos Jerami dan dengan perlakuan kedua (P2) 
Tanah+Tepung cangkang telur sebagai bahan untuk dikaji untuk dijadikan sebagai campuran media tanam.

$$
\text { P1 = Tanah }+ \text { Kompos Jerami }
$$

P2 = Tanah+ cangkang telur

Perlakuan P1 diberikan perlakuan menggunakan tanah 100\% atau sekitar $13 \mathrm{~kg}+$ Kompos Jerami26,810 g, sedangkan Untuk Perlakuan P2 akan di berikan tanah sebanyak $13 \mathrm{~kg}$ dan ditambah dengan pemberian tepung cangkang telur sebanyak 26,810 gr. Dari tiap perlakuan di ulang sebanyak 30 kali sehingga di peroleh 60 satuan percobaan. Dalam metode pengambilan sampel untuk parameter perlakuan dilakukan secara acak. Pengamatan dilakukan pada masa panen tanaman pada 25 HST kemudian parameter yang digunakan yaitu : berat panen segar/bobot basah dan juga daya simpan. Hasil penelitian selanjutnya akan dihitung dengan menggunakan uji T tidak berpasangan (independent sampel $t$-test) dengan $\alpha=5 \%$.

\section{Hasil dan Pembahasan}

\section{Berat Panen/Bobot Basah}

Tanaman kangkung sudah dapat di panen pada saat umur tanaman mencapai 25 hari setelah tanam. Proses panen dilakukan secara manual menggunakan tangan dengan cara mencabut tanaman dari dalam polybag dan memisahkannya dari tanah dan juga kotoran lain yang menempel pada akar dan batang tanaman kemudian di timbang dengan timbangan digital. Penimbangan dilakukan untuk mengetahui berat bobot segar tanaman kangkung dengan satuan gram sehingga dapat diketahui berat keseluruhan tanaman kangkung termasuk bagian akar tanaman. Tanaman di timbang secara satu persatu sesuai urutan perlakuan dan ulangan. Penimbangan hasil keseluruhan ulangan dari setiap perlakuan untuk memperoleh nilai rerata bobot segar tanaman kangkung dari setiap perlakuan.

Hasil penimbangan bobot segar tanaman kangkung dari setiap perlakuan pupuk organik yakni Kompos Jerami (P1) dan juga Tepung cangkang telur (P2) menunjukkan bahwa tanaman yang menggunakan kompos Jerami menghasilkan bobot segar yang lebih tinggi di bandingkan dengan tanaman yang menggunakan Tepung cangkang telur. Adanya penambahan bobot segar pada tanaman kangkung tidak lepas dari peranan unsur hara yang berkontribusi dalam proses pembentukan dan penambahan ukuran dari bagian tanaman seperti daun, batang dan juga akar tanaman hal ini sependapat dengan (Ferry Yunianti, I., dkk, 2016) yang menyatakan bahwa hal ini disebabkan oleh Peningkatan berat segar tidak terlepas dari peningkatan unsur hara seperti nitrogen $(\mathrm{N})$, posfor $(\mathrm{F})$, kalium $(\mathrm{K})$ dimana unsur nitrogen $(\mathrm{N})$ mempengaruhi pembentukan selsel baru, fosfor (F) berperan dalam pengaktifan enzim-enzim dalam proses fotosintesis dan kalium mempengaruhi perkembangan jaringan meristem yang dapat mempengaruhi panjang dan lebar daun. Dengan demikian dapat kita simpulkan bahwa pupuk organik tepung cangkang telur belum mampu menyediakan unsur hara baik dan sesuai untuk kebutuhan tanaman kangkung sehingga hasil panen dari bobot segar menjadi kurang maksimal.

Hasil perbandingan berat bobot basah dengan satuan gram pada tanaman kangkung antara perlakuan pemberian kompos Jerami dan tepung cangkang telur dapat dilihat dari hasil rerata pada Tabel 1 di bawah ini:

Tabel 1. Hasil Uji Bobot Segar

\begin{tabular}{|c|c|c|}
\hline Perlakuan & $\begin{array}{c}\text { Bobot Segar (Gram) Per } \\
\text { Tanaman Pada Saat Panen }\end{array}$ & Keterangan \\
\hline P1 (Kompos Jerami) & 129,70 & TS \\
\hline P2 (Tp Cangkang Telur) & 103,33 & \\
\hline P Value & 0,174 & \\
\hline
\end{tabular}

Keterangan: $\mathbf{T S}=$ Tidak Signifikan,menunjukkan hasil kedua perlakuan tidak berbeda nyata berdasarkan uji T tidak berpasangan $(\alpha=5 \%)$ dengan P Value $=0,174$ 
Dari Tabel di atas dapat dilihat bahwa rerata bobot segar dari tanaman kangkung yang di beri pupuk organik menggunakan kompos Jerami (P1) menghasilkan bobot segar yang hampir sama dengan tanaman yang menggunakan pupuk organik tepung cangkang telur(P2). Hasil penelitian menunjukkan bahwa tanaman yang menggunakan pupuk organik kompos Jerami (P1) memiliki bobot segar dengan persentase $3,33 \%$ sementara tanaman yang menggunakan pupuk organik tepung cangkang telur(P2) memiliki bobot segar dengan persentase 3,33\%. Sehingga selisih persentase bobot segar kedua perlakuan tersebut adalah 0\%. Dengan demikian dapat disimpulkan bahwa pemberian pupuk organik kompos Jerami maupun tepung cangkang telur tidak ada yang lebih unggul satu sama lain sehingga di peroleh hasil yang sama.

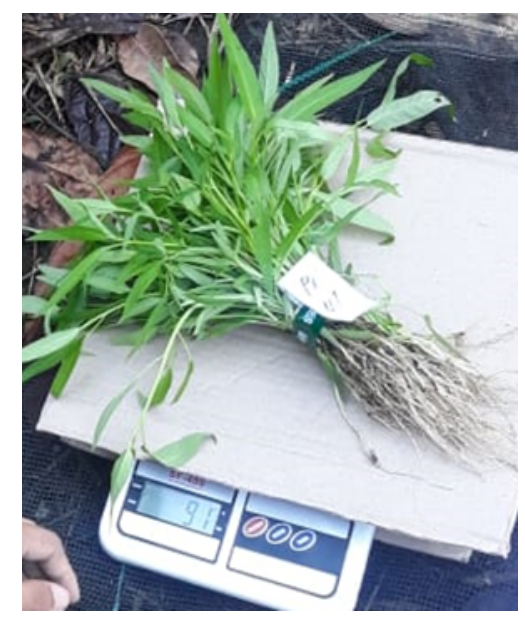

Gambar 1. Perlakuan 1 Kompos Jerami 26, $810 \mathrm{~g}$

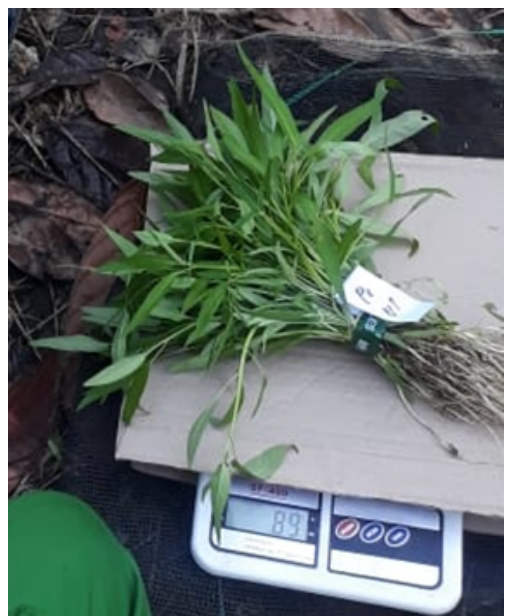

Gambar 2. Perlakuan 2 Tepung Cangkang Telur 26, $810 \mathrm{~g}$

Daya Simpan

Tanaman kangkung yang telah di panen pada umur 25 hari setelah penanaman di bersihkan dari tanah, kotoran dan gulma baik yang menempel di akar maupun batang tanaman. Tanaman yang telah di timbang bobot segarnya berdasarkan jenis perlakuan dan ulangannya yakni Pemberian kompos Jerami (P1) dan juga Tepung cangkang telur (P2) selanjutnya diambil satu tanaman untuk tiap ulangan pada setiap perlakuan secara acak untuk di jadikan sampel pengamatan daya simpan tanaman kangkung guna mengetahui seberapa lama tanaman dapat 
bertahan sebelum di olah. Tanaman kangkung yang telah di pilih menjadi sampel untuk tiap perlakuan yakni sejumlah 60 tanaman selanjutnya di letakkan di atas kertas putih agar mudah mengamati perubahan yang terjadi dimana jika tanaman menunjukkan tanda seperti batang dan daun menyusut maka tanaman tersebut sudah di nyatakan rusak, pengamatan di lakukan dengan mengukur dengan satuan hari di hitung pada waktu pengamatan untuk setiap sampel tanaman kangkung di mulai yakni pukul 16.26 WITA pada 17 April 2021 adapun data hasil pengamatan tanaman dapat dilihat pada Tabel 2.

Hasil pengamatan daya simpan tanaman kangkung dari setiap perlakuan pupuk organik yakni Kompos Jerami (P1) dan juga Tepung cangkang telur (P2) menunjukkan bahwa tanaman yang menggunakan kompos Jerami (P1) menghasilkan daya simpan yang lebih unggul yakni lama simpannya bisa lebih dari 24 jam/1 hari di bandingkan dengan tanaman yang menggunakan Tepung cangkang telur (P2). Adanya kemampuan bertahan lebih lama pada tanaman kangkung tidak lepas dari peranan unsur hara yang berkontribusi dalam proses pembentukan dan penambahan ukuran dari bagian tanaman seperti daun, batang dan juga akar tanaman hal ini sependapat dengan (Adnan.A dkk, 2014) hal ini terbukti menyebabkan tanaman kangkung yang di beri perlakuan kompos jerami lebih unggul karena memiliki bentuk daun yang lebih besar dan juga batang yang lebih panjang di banding dengan tanaman kangkung yang di beri perlakuan tepung cangkang telur. Adanya perbedaan ukuran ini berdampak pula pada daya simpan tanaman kangkung dimana laju oksidasi atau penguapan tanaman kangkung lebih cepat pada perlakuan tepung cangkang telur hal ini dapat di lihat dari tanda adanya proses penguapan dari bahan pangan yakni adanya penyusutan pada bagian tanaman(sayur) dan juga perubahan warna seperti reaksi kecoklatan(Browning) pada bagian bahan pangan(Institute of Food Science and Technology (1974) dalam (Herawati,H.2008) . hal ini sependapat dengan (Herawati,H.2015) yang menyatakan umur simpan produk pangan adalah selang waktu antara saat produksi hingga konsumsi di mana produk berada dalam kondisi yang memuaskan, berdasarkan karakteristik penampakan, rasa, aroma, tekstur, dan nilai gizi Faktor-faktor ini yang menyebabkan terjadinya perubahan pada produk pangan menjadi dasar dalam menentukan titik kritis umur simpan suatu produk. Hal ini juga sependapat dengan Floros (1993) dan Gnanasekharan (1993) dalam (Herawati,H.2008) kriteria kedaluwarsa beberapa produk pangan yang dapat ditentukan dengan menggunakan acuan titik kritis untuk sayuran yang kering akibat penyerapan uap air atau sering di istilahkan Offflavor. Dengan adanya hasil yang di dapatkan dapat kita simpulkan bahwa pupuk organik tepung cangkang telur belum mampu membuat hasil tanaman kangkung dapat bertahan lebih lama di banding dengan tanaman yang di beri pupuk kompos jerami sehingga hasil daya simpan yang dihasilkan pun menjadi kurang maksimal dapat dilihat pada gambar:

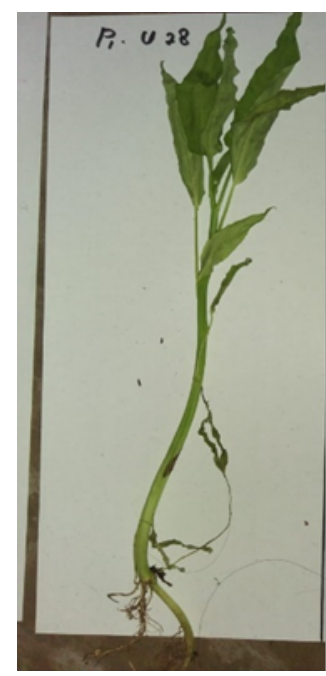

Gambar 3. Perlakuan 1, 24 Jam Setelah Panen

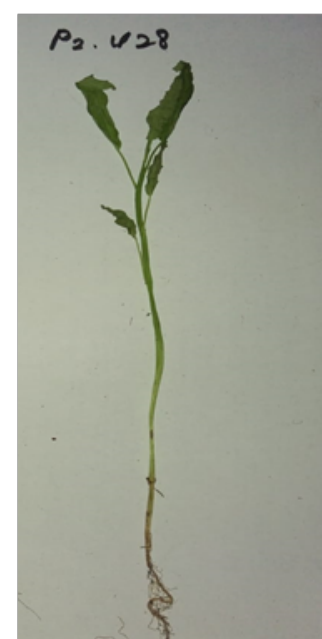

Gambar 4. Perlakuan 2, 24 Jam Setelah Panen 


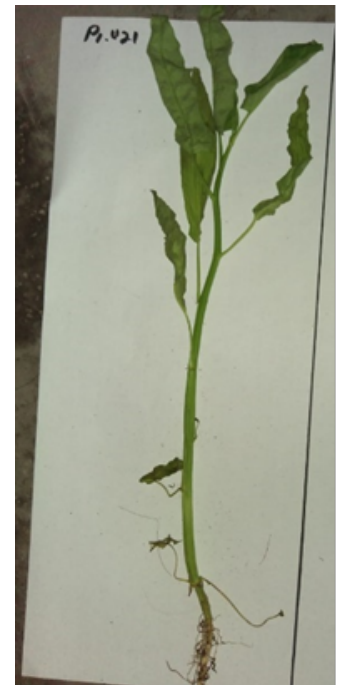

Gambar 5. Perlakuan 1, 48 Jam Setelah Panen

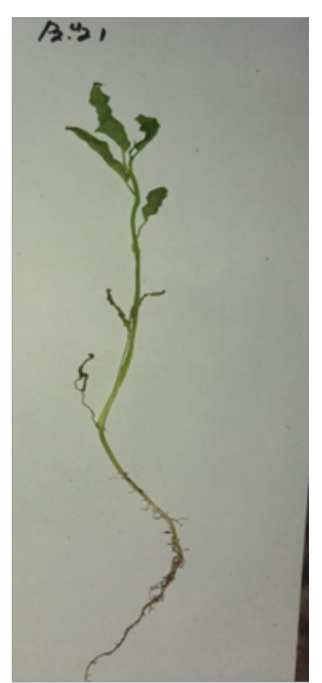

Gambar 6. Perlakuan, 248 Jam Setelah Panen

Tabel 2. Hasil Uji Daya Simpan

\begin{tabular}{|c|c|c|}
\hline Perlakuan & $\begin{array}{c}\text { Daya Simpan (hari) } \\
\text { Per Tanaman Pasca } \\
\text { Panen }\end{array}$ & Keterangan \\
\hline P1 (Kompos Jerami) & 1,70 & TS \\
\hline P2 (Tp Cangkang Telur) & 1,47 & \\
\hline P Value & 0,069 & \\
\hline
\end{tabular}

Keterangan: $\mathbf{T S}=$ Tidak Signifikan,menunjukkan hasil kedua perlakuan tidak berbeda nyata berdasarkan uji T tidak berpasangan $(\alpha=5 \%)$ dengan P Value $=0,069$

Dari tabel di atas dapat dilihat bahwa rerata daya simpan dari tanaman kangkung yang di beri pupuk organik menggunakan kompos Jerami(P1) memiliki daya simpan yang sama dengan tanaman yang menggunakan pupuk organik tepung cangkang telur(P2). Hasil penelitian menunjukkan bahwa tanaman yang menggunakan pupuk organik kompos Jerami(P1) memiliki daya simpan 1,7 atau 3,33\% sementara tanaman yang menggunakan pupuk organik tepung cangkang telur(P2) memiliki daya simpan 1,47 atau 3,33\%. Sehingga selisih persentase bobot segar kedua perlakuan tersebut adalah 0\%. Dengan demikian dapat disimpulkan bahwa pemberian pupuk organik kompos Jerami maupun tepung cangkang telur tidak ada yang lebih unggul satu sama lain sehingga di peroleh hasil yang sama.

\section{Kesimpulan}

Hasil Penelitian Menunjukkan tidak terdapat perbedaan nyata dari bobot segar tanaman kangkung hal ini dapat dilihat bahwa P1(kompos Jerami) memiliki rerata berat 129,70 g sedangkan untuk perlakuan P2 (tepung cangkang telur) dengan rerata berat 103,33 g. Dengan demikian dapat disimpulkan bahwa tidak ada perbedaan yata dari ke-2 perlakuan yang di berikan. 


\section{Ucapan Terimakasih}

Kepada saudara(i) Irlan gurawal dan Maria Grasela Meo atas sumbangsi saran serta masukannya dalam penulisan karya ini saya mengucap banyak terimakasih untuk kontribusinya,tak lupa pula untuk ibu Irianti Kurniasari yang sudah memberi saran kepada saya(penulis).

\section{Referensi}

Adnan, A., Rasyad, A., \& Armaini. (2014). Pertumbuhan Dan Hasil Tanaman Kangkung Darat (Ipomea Reptans Poir) Diberi Trichokompos Jerami Padi (Doctoral dissertation, Riau University). Jurnal Agroteknologi Universitas Riau.

Herawati, H.(2008). Penentuan Umur Simpan Pada Produk Pangan. Jurnal Litbang Pertanian. 27 (4),124-130.

Ferry., Yunianti, I., \& Mellyga Wangga Paputri dan Prihasto Setyanto Balai Penelitian Lingkungan Pertanian Jl Raya Jakenan-Jaken, D. (2016). Pengaruh Pemberian Pupuk Anorganik Dan Organik Terhadap Pertumbuhan Dan Hasil Tanaman Kangkung Di Lahan Tadah Hujan. BB Pengkajian dan Pengembangan Teknologi Pertanian. from http://repository.pertanian.go.id/handle/123456789/6538

Rohmawati, D. (2016). Pembuatan Kompos Dengan Mol Limbah Organik. Yogyakarta.

Syam, Z. Z., Kasim, H. A., \& Nurdin, H. M. (2014). Pengaruh Serbuk Cangkang Telur Ayam Terhadap Tinggi Tanaman Kamboja Jepang (Adenium obesum) Effect of Chicken Egg Shell Powder Plant Growth Cambodja Against Japan (Adenium obesum).E-JIPBIOL. 3 (2), 9-15. http://jurnal.untad.ac.id/jurnal/index.php/EBiol/article/view/2697

\begin{tabular}{|l|l|}
\hline Muhammad Nur Ichwan & $\begin{array}{l}\text { Program Studi Penyuluhan Pertanian Berkelanjutan Polbangtan } \\
\text { Malang } \\
\text { E-mail: } \text { muhammadnurichwan5@gmail.com }\end{array}$ \\
\hline Sutoyo & $\begin{array}{l}\text { Staf Pengajar Program Studi Penyuluhan Pertanian Berkelanjutan } \\
\text { Polbangtan Malang } \\
\text { E-mail: } \text { oyotus78@gmail.com }\end{array}$ \\
\hline $\begin{array}{l}\text { Eny Wahyuning } \\
\text { Purwanti }\end{array}$ & $\begin{array}{l}\text { Staf Pengajar Program Studi Penyuluhan Pertanian Berkelanjutan } \\
\text { Polbangtan Malang } \\
\text { E-mail: } \text { enywah17@gmail.com }\end{array}$ \\
\hline
\end{tabular}

